\title{
ULBP3 wt Allele
}

National Cancer Institute

\section{Source}

National Cancer Institute. ULBP3 wt Allele. NCI Thesaurus. Code C105593.

Human ULBP3 wild-type allele is located in the vicinity of $6 \mathrm{q} 25$ and is approximately $7 \mathrm{~kb}$ in length. This allele, which encodes NKG2D lig and 3 protein, plays a role in the production of both cytokines and chemokines by natural killer cells. 